\title{
Beyond the rhetoric of international human rights standards in the struggle to decriminalise homosexual conduct in Uganda
}

\author{
Emma Charlene Lubaale \\ Department of Jurisprudence, School of Law, University of Venda, South Africa
}

\begin{abstract}
In 2014, Uganda's Constitutional Court struck down the problematic Anti-Homosexuality Act (AHA). However, since the decision of the court was based on procedural rather than on substantive grounds, the AHA may very well be reintroduced, or, other anti-homosexuality laws in place can still be relied on to criminalise consensual homosexual conduct. The ideal solution is to have all the anti-homosexuality laws struck down in light of Uganda's international human rights obligations. However, although a number of international human rights instruments lend impetus to the cause of decriminalisation in Uganda; these international standards have thus far not fully persuaded Uganda to have these discriminatory laws struck down. In this article, I argue that whereas arguments based on Uganda's international and constitutional obligations form a good foundation for reform, these standards cannot of themselves form a complete solution to the problem. Drawing on the various actors that were at the fore in the struggle towards the striking down of the AHA, I argue that translating the rights of lesbian, gay and bisexual and transgender (LGBT) people into a reality will require conscious efforts from a number of actors including the judiciary, international and national human rights defenders and faith-based organisations. I identify some of the mistakes made by the foregoing actors in advocating for the striking down of the AHA, and how these mistakes should be addressed if the cause of decriminalisation is to be effectively advanced. Although Uganda is placed at the heart of the discussion, the conclusions drawn are relevant to other African countries battling with this subject.
\end{abstract}

Key words: Uganda, international human rights standards, Anti-Homosexuality Act, decriminalisation

\section{Introduction}

Even before the Anti-Homosexuality Bill (AHB) put Uganda in the world's spotlight, the debate on whether or not homosexuality should be criminalised had been on-going. This debate only escalated with the tabling of the AHB in Uganda's parliament in 2009 which expressly criminalised homosexuality. This Bill which later became law in 2014 was struck down by Uganda's Constitutional Court on I August 2014. Uganda's Constitutional Court did not pronounce itself on the criminality of consensual homosexual acts. The import of this is that homosexuals are still categorised as criminals since there 
are other laws in place which have over the years been broadly interpreted to encompass consensual homosexual acts. Thus, in this article, I argue that these other laws need to be struck down if the rights of LGBT people in Uganda are to be effectively protected. The foregoing cause, however, cannot be furthered by exclusive reference to international standards. Since the problematic nature of the repealed Act has been extensively articulated upon in other works, ${ }^{1}$ here the discussion is limited to the limits of international standards, hence the need to continuously give due regard to other attendant actors. Therefore, following this introduction, a brief background of the AHA is given. Subsequently the international standards that lend impetus to the cause of decriminalisation of homosexual conduct are discussed. Having underscored the limits of international standards, the final section extensively discusses how selected attendant actors should creatively execute their roles to ensure that homosexual conduct is decriminalised and most importantly that an environment is created for the rights of LGBT people to be effectively guaranteed.

\section{Background of anti-homosexual laws in Uganda}

The laws in Uganda which expressly or implicitly criminalise homosexuality are a legacy of colonial rule. Uganda, having been colonised by Britain and only gaining independence in 1962 was very much influenced by Britain's legal norms. As of 1902 , British laws criminalised unnatural offences on account of their alleged immoral nature. Homosexuality, though not expressly mentioned, was implicitly categorised as an unnatural offence. Criminalisation of unnatural offences was imported to Uganda by the wave of colonialism. Although Uganda became independent of British rule, it inherited many British founded laws including the penal laws. The Penal Code Act of 1950 which was and continues to be the major penal statute of Uganda was one of the inherited laws. The Penal Code Act has over the years been a subject of amendment but these amendments have not impacted offences such as unnatural offences. Presently, section 145 (a) of the Penal Code Act is the generally cited provision in as far as the criminality of homosexual conduct in Uganda is concerned. The section provides that '[a]ny person who has carnal knowledge of any person against the order of nature commits an offence and is liable to imprisonment for life.' Section 145 (a) neither identifies homosexual acts nor homosexual orientation as conduct against the order of nature. However, the continued interpretation of section 145 (a) to encompass homosexual acts is in accord with the definition of unnatural offences by some courts outside Uganda. In the case of Magaji $v$ The Nigerian Army (2008), the Supreme Court of Nigeria ruled that 'carnal knowledge is an old legal euphemism for sexual intercourse with a woman.' The court added that since 'the order of nature is carnal knowledge [between a male] with the female sex, carnal knowledge Anti-Homosexuality Act (AHA) as well as the effect it has on the Ugandan LGBTI community. On these issues, see e.g. Tamale (2009). Since as noted in the text these issues have already been dealt with comprehensively by other commentators, this article will not delve into this aspect. However, just briefly, the AHA had major implications for the right to health, right to equality before the law, freedom from discrimination, etc. 
with the male sex is against the order of nature.' Order of nature, according to the court meant 'God and not just the generic universe that exists independently of mankind or people.' Note, however, that although Uganda's laws against homosexual conduct purport to regulate conduct and not status, the reality is that criminalising sexual conduct between partners of the same sex has had the effect of marking individuals as criminal on the basis of their sexual orientation.

In terms of the supreme law of Uganda, the 2005 constitutional amendment, under article $3 \mathrm{I}(2)$ introduced a new provision prohibiting marriage between persons of the same sex (The Constitution of the Republic of Uganda, 1995). This provision gradually made its way into the constitution following growing impetus to criminalise homosexuality. This was quite unusual to the extent that the Constitution was forced to take on the nature of a penal statute.

Despite the above provisions, some Ugandans, including religious leaders and parliamentarians were convinced that the position of Uganda's codified criminal law was not strong enough to curb homosexuality. As argued, the existent laws were too weak to address this pervasive problem (see content of Kasha Jacqueline, David Kato and Onziema Patience v Rolling Stone Publications Limited and Giles Muhame (Rolling Stone case), 2010). It was further contended that implementation of existing laws was poor (Rolling Stone case, 2010). Scott Lively one of the American religious leaders backing up many Ugandans on the issue was of the view that cohesion of the African family was being threatened by 'homosexuals looking to recruit youths in ranks' (Civil Society Coalition on Human Rights and Constitutional Law (CSCHRCL) and Human Rights Awareness and Promotion Forum (HRAPF), 2013). Lively was confident that the AHB was a needed reaction to attempts by Americans and Europeans to 'homosexualise' Ugandan society (CSCHRCL \& HRAPF, 2013). Many conservatives were of the view that a new law that deals comprehensively with the issue of homosexuality would address this so called 'international gay agenda.' There was therefore need, as it were, for tougher laws that encompass 'hanging dozens of homosexuals [to ensure that] the moral fabric and culture [of Uganda's] great nation [is preserved]' (Rollingstone case, 2010:3). David Bahati, the member of parliament of Ndorwa was the vessel through which the AHB was introduced to Uganda's parliament in 2009. According to Bahati, with the passing of the law, family life, African moral values and Uganda's children would be guaranteed protection from the western immoral homosexual agenda (Rwakabamba, 2014). Taken together, the AHB, as argued by adherents, sought to strengthen the nation's capacity to deal with emerging internal and external threats to the traditional heterosexual family, to protect the legal and religious values of Ugandans and to protect children from being raised by parents in homosexual relationships.

With the tabling of the AHB in Uganda's parliament, homophobia in Uganda became pervasive with violence against LGBT people escalating. It was during this period that names and physical addresses of suspected homosexuals in Uganda were published in one of Uganda's newspapers (See Rolling Stone case in which the publication was challenged). This publication was followed by the death of David Kato, one of the prominent 
LGBT activists whose name and address had earlier been published in the media (New York Times, 20II). David Kato was attacked in his own home following an earlier publication containing a list of alleged homosexuals. Amidst the escalated levels of homophobia and the need to impose severe sanctions on persons who engage in homosexual acts in Uganda, the Anti-Homosexuality Act (AHA) was finally assented to by the president of Uganda, Yoweri Museveni in 2014 (a milestone that the majority of Uganda's populace deemed a victory well deserved). ${ }^{2}$ The AHA, amongst others created the offences of homosexuality, aggravated homosexuality and attempted homosexuality under sections 2, 3 and 4 respectively, all carrying a maximum sentence of life imprisonment (see AntiHomosexuality Act as struck down). The criminalisation of same-sex conduct in Uganda (before and after the enactment of the AHA) has had far reaching negative consequences for LGBT people, most notably, arbitrary killings; arbitrary arrests and detention; discrimination in various arenas including the criminal justice system and the healthcare system; denial of freedom of expression, assembly and association; amongst other fundamental rights (CSCHRCL \& HRAPF, 2013: I-87). The foregoing violations, when measured against international standards present a persuasive basis for decriminalisation of homosexual conduct in Uganda. But Uganda fails to be persuaded to effectively draw from the grounded international standards. The next section briefly unpacks these standards with a view to lending impetus to the argument that they cannot function on their own.

\section{The limits of international standards in furthering the cause of decriminalisation}

International human rights standards are frequently cited as a basis for decriminalisation of homosexual conduct. Uganda's laws against homosexual conduct violate a series of international standards which Uganda is a party to. ${ }^{3}$ One such international instrument is the International Covenant on Civil and Political Rights (ICCPR). The ICCPR has a host of provisions which if broadly interpreted and applied further the cause of decriminalisation of consensual homosexual acts among adults. Article 2 of the ICCPR requires each state party to ensure to all individuals within its territory and subject to its jurisdiction the rights recognised in the ICCPR without distinction of any kind, such as race, colour, sex, language, religion, political or other opinion, national or social origin, property, birth or other status. Article 26 of the ICCPR goes on to guarantee the right

2

The Bill was signed by the president on 24 February 2014.

Uganda is a party to several international human rights instruments that lend impetus to the argument of decriminalisation of homosexual conduct. This is evident in Uganda's commitment to international law through the ratification of various international instruments that directly impact the rights of LGBT people. On Uganda's international obligation by virtue of ratification, see status of ratification of the African Charter on Human and Peoples' Rights indicating that Uganda ratified the ACHPR on ro May 1986; indicating that Uganda ratified the International Covenant on Civil and Political Rights on 2I June 1995; indicating that Uganda ratified the International Covenant on Economic Social and Cultural Rights on 21 January 1987; indicating that Uganda ratified the United Nations Convention on the Rights of the Child on 17 August I990; indicating that Uganda ratified the United Nations Convention Against Torture on 3 November 1986, amongst others. 
of all persons to equality before the law without any discrimination. Grounds such as race, colour, sex, language, religion, political or other opinion, national or social origin, property, birth or other status, are expressly mentioned. Article 17 of the ICCPR prohibits arbitrary or unlawful interference with a person's privacy, family, home or correspondence as well as the unlawful attacks on the person's honour and reputation. These rights have equally been guaranteed in Uganda's Constitution.

The Human Rights Committee has also made pronouncements on the implication of some national penal laws on the provisions of the ICCPR. For instance, the Human Rights Committee has gone to great lengths to interpret the provisions of the ICCPR as to encompass a prohibition of criminalisation of consensual homosexual acts among adults. The 1994 case of Toonen $v$ Australia (1994) (Toonen case) is one notable case where the generous and broad application of the ICCPR to the rights of LGBT people was brought to the fore. In this case, Toonen an Australian man petitioned the Human Rights Committee challenging two provisions of the Tasmanian Criminal Code that criminalised homosexual acts between men. By holding that the references to 'sex' in the ICCPR were to include 'sexual orientation,' the Human Rights Committee ruled that the statute was in violation of the ICCPR (article 2(I) of the ICCPR; article 26 of the ICCPR; Toonen case, 1994: para 8.7). Although the Human Rights Committee preferred to categorise sexual orientation within the broader ambit of discrimination on grounds of 'sex', an argument could equally be advanced to the effect that 'other status' as used in article 26 of the ICCPR encompasses sexual orientation. The Committee ruled further that it was undisputed that adult consensual sexual activity in private was covered by the concept of privacy (Toonen case, 1994: para 10). As such, by criminalising this conduct, Australia had violated its conventional obligation provided by Article 17 of the ICCPR. The Committee stated that it was unacceptable for purposes of Article 17 of the ICCPR that moral issues be raised as a defense for impermissible restrictions on privacy (Toonen case, 1994: para 8.6).

At the regional level, the African Commission of Human and People's Rights (African Commission) has also made explicit its position on the rights of LGBTI people. In Resolution 275, on the Protection against Violence and other Human Rights Violations against Persons on the basis of their real or perceived Sexual Orientation or Gender Identity, the African Commission made a number of interesting pronouncements (2014), all of which are geared towards affirming the protection due LGBTI people. Notably, the African Commission condemned the increasing incidence of violence against LGBTI people, by both the state and non-state actors (para I). The Commission also called upon States to take measures to protect LGBTI people (para 2). It deemed it fit that such protection should not just extend to LGBTI people but also, to human rights defenders (para 3). In the latter case, the African Commission implored States to create an environment that ensures that human rights defenders are not stigmatised or subjected to criminal prosecution as a result of conducting activities geared towards advancing the rights of LGBTI people (para 3). The Resolution also takes cognizance of a number of provisions within the African Charter, whose generous interpretation, can found a basis for the protec- 
tion of the rights of LGBTI people (Preamble). Notable ones include the right to equal protection of the law under article 2 and the right to freedom from discrimination under article 3 (Preamble).

A host of other international human rights instruments, through their General Comments, ${ }^{4}$ also provide a sufficient basis for the decriminalisation of consensual homosexual conduct. The Committee on Economic, Social and Cultural Rights has provided an authoritative interpretation of Article 2(2) of the International Convention on Economic, Social and Cultural Rights in General Comment No. 20, explicitly stating that discrimination on the grounds of sexual orientation and gender identity are covered by the 'other status' clause of Article 2(2) (General Comment no. 20, 2009). Similarly, the Committee on the Rights of the Child, through its General Comment No. 4, has pointed out that article 2 of the Convention of the Rights of the Child covers sexual orientation and health status (General Comment no.4, 2003). The UN Committee against Torture has also explained in General Comment No. 2 that laws in relation to fulfilling obligations under the UN Convention against Torture must be applied to all persons, regardless of sexual orientation and transgender identity (General Comment No. 2, 2008). The Yogyakarta Principles (2006) summarise the application of international law to human rights violations based on sexual orientation and gender identity. ${ }^{5}$ At the regional level, article 2 of the African Charter on Human and Peoples' Rights (ACHPR) underscores the right of every individual to enjoy the rights and freedoms recognised and guaranteed in the ACHPR without distinction of any kind such as race, ethnic group, colour, sex, language, religion, political or any other opinion, national and social origin, fortune, birth or any status. The foregoing provision can be interpreted as prohibiting discrimination on the grounds of sexual orientation under the 'any status' clause.

In terms of the grounded international norms briefly expounded above, had the protection of the rights of LGBT people simply been a matter of drawing on international human rights norms, homosexual conduct would have long been decriminalised in Uganda. The fact that Uganda fails to heed to these norms suggests that more needs to be done. Viljoen, in his book discussing international human rights law in Africa has correctly observed that 'without doubt, most African states do not comply with the views issued by [monitoring bodies of international human rights conventions]' (Viljoen, 2007: II7). Sadgrove et al. (2012: 108) add that in Africa, 'there are still deeply rooted difficulties with the transcultural application of human rights concepts as they are received into local

General Comments are guidelines by human rights expert committees, providing an authoritative interpretation of the rights contained in the articles and provisions of international human rights conventions and how they apply to thematic areas. Each of the treaty bodies publishes its interpretation of the provisions of its respective human rights treaty in the form of "General Comments" or "general recommendations." In terms of the weight attached to General Comments, theoretically, they are not binding. However, they carry considerable legal weight.

5 These Principles outline a set of international principles relating to sexual orientation and gender identity, providing a universal guide to human rights which affirm binding international legal standards with which all States must comply. The Yogyakarta Principles are not legally binding. However, they draw inspiration from international treaties that Uganda is a party to. 
epistemologies.' African states are also on record for their reluctance to adhere to the standards set by their own monitoring bodies at the regional level (Hopkins, 2002: 23425I; Viljoen \& Louw, 2007: I-34)). Moreover, it appears that several actors, most notably the executive, the parliament, the media and some religious leaders have substantially changed the narratives around the AHA for selfish ends (Strand, 275-294). The foregoing could suggest that to ultimately decriminalise consensual homosexual conduct, efforts must go beyond merely drawing on international standards.

\section{The role of selected actors in practically realising the rights of LGBT people in Uganda: lessons from the previous struggle against the AHA}

Stychin (2004: 965) has asserted that 'gay rights arguments will win the day because of their easy articulation as part of globalisation discourse.' To Stychin (2004: 965) 'the language of rights cannot... apolitically provide resolutions to these moments. Legal claims have led to results but a turn to law does not mask the political character of the dispute and its outcome.' Although a small section of Uganda's populace is open to the idea of decriminalisation of homosexual conduct, for Uganda, where the majority of Ugandans takes a contrary view and where international standards and legal philosophies are viewed with suspicion, Stychin could be correct to aver that human rights are limited. Conceivably, human rights should merely be used by different actors as a tool in making a case for decriminalisation. Accordingly, the judiciary, faith-based organisations, international human rights defenders and national human rights defenders are identified as key actors in ensuring that the rights of LGBT people become a reality. The potential of these actors in ensuring that human rights standards have effect at the national level was already evident in previous struggles which saw the AHA struck down. However, with regard to some of these actors, the section identifies some of the mistakes previously made and how these mistakes should be addressed if the cause of decriminalisation is to be effectively furthered.

\section{The judiciary}

In the struggle for decriminalisation of laws which are popular to the majority of the populace, the judiciary, through the process of constitutional review, plays a critical role. Constitutional review generally refers to the courts' review of a statute, regulation, directive, administrative or judicial action to determine its consonance with a country's constitution. Often, the legislature and the executive, who largely depend on the majority for support, prefer to subscribe to the views of the majority in society. Hence, minorities may most likely, never, on their own, or even with the support of the legislature and the executive, be able to use political power to secure legislation in their favour. Thus within this realm, the majoritarian opinion can be harsh to minorities who exist outside the mainstream. Thus, constitutional review stands out as a counter-majoritarian process, not exclusively reliant on public opinion to determine constitutional issues but bound by the constitution itself. This subsection assesses the role of Uganda's judiciary in executing its constitutional review roles. 
Even before the tabling of the AHB in Uganda's parliament, Uganda's judiciary adjudicated over cases which created an opportunity for the international and constitutional standards to be invoked. In the 2008 case of Mukasa and Another $v$ Attorney-General (Mukasa case) (2008), Local Council officials forcibly entered the home of Victor Mukasa (an LGBT person), confiscated documents, arrested the person they found at the home, took her to the police station, undressed her, fondled her breasts and later released her without a charge. At the police station, she was undressed to 'confirm' her sex, jeered at while at the Police Station, referred to as a 'disgraceful creature' and denied the opportunity to make use of toilet facilities. The High Court of Uganda, per Arach Amoko J found that the applicants' rights to privacy, personal liberty and freedom from torture, cruel, inhuman and degrading treatment as guaranteed under Uganda's Constitution and other international treaties that Uganda is a party to, were violated (paras 42-45). Admittedly, the dictum in the Mukasa case demonstrates the preparedness of Uganda's judiciary to protect the rights of all people including LGBT people. It is, however, evident that although the court in the Mukasa case underscored the need to guarantee the fundamental rights of the applicants, the court preferred not to pronounce itself on the constitutionality of the alleged applicants' homosexual conduct which in fact formed the basis of the human rights violations identified by Arach Amoko J.

Again in 20ro, in the Rolling Stone case, the Rolling Stone, a media company issued its fifth publication on 2 October 20ro. Its front page carried the headline 'roo Pictures of Uganda's Top Homos Leak' which included the words 'Hang them!' Bullet points under the headline read, 'we shall recruit 100,000 innocent kids by 2012: Homos' and 'Parents now face heart-breaks as homos raid schools.' The paper contained the names and in some cases the pictures and description of the physical addresses of certain activists and human rights defenders. A later edition of the newspaper published on 3 I October 2010 contained a further 17 photos of alleged LGBT people, with personal details of those identified, including their physical addresses. The applicants petitioned Uganda's High Court seeking a permanent injunction restraining the respondents from publishing injurious information against them. It was their argument that such publication threatened their right to life, dignity, liberty, privacy, amongst other rights. The High Court per Kibuuka-Musoke J held that the publication threatened the applicants' right to life, violated their right to dignity and privacy (Rolling Stone case, 2010: 9). The ruling of the court in this case also signifies progress. Note, however, that in the Rolling Stone case, the presiding judge was very quick to expressly caution that 'it must be noted that this application is not about homosexuality' (Rolling Stone case, 2010: 9). Kibuuka-Musoke J added that 'section 145 of the Penal Code Act [does not] render every person who is gay a criminal under that section of the Penal Code Act. The scope of section 145 is narrower than gayism generally. One has to commit an act prohibited under section 145 in order to be regarded as a criminal' (Rolling Stone case, 2010: 9). It can be garnered from the foregoing dicta that in fact, consensual homosexual acts are still criminal in Uganda. And with the elaboration of the High Court in this case, the ambiguous section I45(a) of the Penal Code Act is clothed with content. On balance therefore, the courts seem to resile from the 
majority view not to guarantee the rights of LGTB people but at the same time they do not seem prepared to go all the way to decriminalise consensual homosexual acts. This is to the extent that in his judgement in the Rolling Stone case, Kibuuka-Musoke J had to make it clear that violation of the mentioned rights did not necessarily mean homosexuality was legal.

In the 2014 case of Professor J Oloka-Onyango \& Others $v$ Attorney General of Uganda (Oloka-Onyango case), the petition amongst others challenged the AHA on grounds that:

- It was enacted by the parliament of Uganda without the requisite quorum,

- The criminalisation of consensual same sex sexual activity among adults in private was a contravention of the constitutionally guaranteed right to privacy,

- In criminalising touching by persons of the same sex, the AHA created an offence that was overly broad and in consequence contravened the principle of legality as guaranteed under article 28 of the Constitution of Uganda,

- In imposing a maximum life sentence for homosexuality, the AHA provided for a disproportionate punishment for the offence and consequently contravened the constitutionally guaranteed right to equality and freedom from cruel, inhuman and degrading punishment,

- In imposing a maximum life sentence for attempted homosexuality, the AHA provided for a disproportionate punishment for the offence and consequently contravened the constitutionally guaranteed right to equality and freedom from cruel, inhuman and degrading punishment. ${ }^{6}$

The petitioners consequently prayed in aid, amongst others, for the offence of homosexuality, aggravated homosexuality and attempt to commit homosexuality under the AHA to be declared null and void. Amongst the orders that the petitioners sought were for the court to permanently stay the coming into force of the Statute.

In hearing the petition, the submissions of the applicants and the respondents did not go beyond the procedural technicality on parliamentary quorum. The merits of the case in terms of the substantive content of the AHA were barely engaged and the court equally did not venture into pronouncing itself on these issues. The court categorically pointed out that the simple issues that emerged were:

- Whether the AHA was passed in accordance with the law and

- Whether the petitioners had proved that during the enacting process of the AHA, the speaker ignored objections pertaining to the absence of requisite quorum at the time the Bill was put to vote (Oloka-Onyango case 2014: I6).

6 Notable Ugandan cases in which equality and non-discrimination have been given detailed articulation include Law Advocacy for Women in Uganda v Attorney General Const. Petitions Nos. 13/05/\& 05/06 [2007] UGCC I at I0-II; Tumukunde v Attorney General \& Another Const. Petition No. 6 of 2005 [2005] UGCC I; Darlington Sakwa \& Another v Electoral Commission \& 44 Others Const. Petition No. 8 of 2006 [2006] UGCC 3 at 1-2. 
In resolving these two issues, the court reasoned that since quorum in accordance with the rules of procedure of Uganda's parliament meant at least a third of all the members entitled to vote, a requirement that was not adhered to, the passing of the AHA without quorum by parliament was inconsistent with and in contravention of Articles 2(I) and (2) and 88 of the Constitution of Uganda and thus null and void (Oloka-Onyango case 2014: 20). Having arrived at the foregoing conclusion, the Constitutional Court did not hear the merits of the petition as it pertained to the substantive content of AHA. In this regard the Constitutional Court categorically pointed out that ' $[t]$ he issue [on quorum] therefore disposes of the whole petition. Having found in the affirmative on Issue I [on quorum], we find that that has the effect of resolving the entire Petition. The Petition is therefore, hereby allowed' (Oloka-Onyango case 2014: 22).

In the Oloka-Onyango case, the Court's ruling on the issue of quorum disposed of the other substantive issues. It must therefore be acknowledged that Uganda's judiciary carried out its judicial role by striking down the law. However, failure of Uganda's Constitutional Court to explicitly address the issue whether the criminalisation of consensual homosexual acts is in accord with fundamental human rights standards deprived the homosexuality debate in Uganda of what would otherwise have been an authoritative point of reference in the protection of the rights of LGBT people. The foregoing uncertainty still leaves the constitutionality of homosexual conduct in the balance since the decision of the court was based on procedural rather than substantive grounds, to which end new legislation (in accordance with the requisite quorum) may very well be reintroduced. In fact, members of the Ugandan parliament have already drafted a new bill. Moreover, although the AHA (now struck down) was the first of Uganda's laws to expressly criminalise homosexuality in Uganda, as alluded to earlier, section I45(a) of the Penal Code Act has over the years been relied upon to advance the cause that the AHA was seeking to achieve, which is to criminalise homosexuality and more particularly homosexual acts. What this means is that the striking down of the AHA merely removes the element of express criminalisation of homosexuality. Arguably, if the Constitutional Court had pronounced itself on the merits of the petition, the judgment of the court would have gone a long way in impacting the interpretation of section 145 (a) of the Penal Code Act which although unchallenged to date, remains a basis for the criminalisation of consensual homosexual conduct.

Conversely, South Africa's judiciary, through the process of constitutional review, has risen to the challenge of stepping up its protection of LGBT people. The experience of South Africa is perhaps the most persuasive for Ugandan courts in light of the fact that they are both on the African continent. South Africa's judiciary has not succumbed to the fear of democratic illegitimacy. The Constitutional Court of South Africa has aggressively struck down laws that discriminate against LGBT people, underscoring that everyone is equal before the law and has the right to equal protection and benefit of the law. These decisions have been arrived at following detailed substantive interpretation and application of constitutional rights, international human rights norms and foreign law. The court's detailed approach has had the effect of eliminating speculations about 
the criminality of homosexual conduct in South Africa. In National Coalition for Gay and Lesbian Equality v Minister of Justice (Sodomy case) (1998) the Constitutional Court, in striking down the anti-discriminatory laws at issue, ruled amongst others that

The criminalisation of sodomy in private between consenting males is a severe limitation of a gay man's right to equality in relation to sexual orientation, because it hits at one of the ways in which gays give expression to their sexual orientation. It is at the same time a severe limitation of the gay man's rights to privacy, dignity and freedom. The harm caused by the provision can, and often does, affect his ability to achieve self-identification and self-fulfillment. The harm also radiates out into society generally and gives rise to a wide variety of other discriminations, which collectively unfairly prevent a fair distribution of social goods and services and the award of social opportunities for gays (Sodomy case, 1998: para 36).

The Constitutional Court added that 'at the heart of equality jurisprudence is the rescuing of people from a caste-like status and putting an end to their being treated as lesser human beings because they belong to a particular group'(Sodomy case, I998: para 129). In the Sodomy case, the Court went ahead to strike down all discriminatory laws, finding them unconstitutional. Subsequent decisions of South Africa's Constitutional Court have continued to advance the pace set in the Sodomy case (e.g. National Coalition for Gay and Lesbian Equality and Others $v$ Minister of Home Affairs and Others; Fourie v Minister of Home Affairs).

With the explicitness of South Africa's Constitutional Court on the discriminatory nature of anti-homosexuality laws, it is hard to argue that Uganda's judiciary effectively executed its constitutional review role in all the above discussed cases, particularly in the Oloka-Onyango case where the constitutional review opportunity was presented to Uganda's Constitutional Court. Note moreover that the anti-discriminatory laws in South Africa were not generally overturned in the context of a populace that embraced homosexuality. In fact they were overturned in a climate that closely mirrors that of Uganda today. It is fair comment to assert that although Uganda's judiciary struck down the AHA 2014, it abdicated its legal responsibility to decide constitutional human rights issues in a neutral and independent manner, a mistake that will need to be addressed in the subsequent struggles to strike down the other discriminatory laws that are still in place. Thus, although the current human rights standards are undoubtedly straightforward in arming Uganda's judiciary with the requisite tools to decriminalise homosexual conduct, Uganda's judicial officers will need to be more proactive and progressive in the future.

For recommendatory purposes, a sound line of argument that Uganda's judiciary can draw on in arriving at more substantive decisions in the future is the equality argument. As Petrova puts it, equality and non-discrimination are instrumental in defending the rights of LGBT people since 'equality is understood in a unified human rights framework as a right equally applicable to people of different sexual orientation or gender identity' (2013: 497). Thus, the notion of equal worth and dignity of every one (including LGBT people) would lend impetus to the cause of striking down all discriminatory laws. 
The right of LGBT people not to be discriminated against would be understood as a free standing right, invariably tied to the right to equality. Fortunately, the Ugandan Constitution enshrines the principles of equality and non-discrimination in strong terms (The Constitution of Uganda, 1995: article 21). In light of these constitutional guarantees, in future, Uganda's judiciary can draw on the existing Ugandan jurisprudence in which the principles of equality and non-discrimination have been instrumental in defending constitutionally guaranteed rights. ${ }^{7}$

\section{International support and pressure}

International pressure can be successful in preventing anti-LGBT laws from becoming extreme. It can equally be a basis for provision of remedial measures for LGBT people in instances where there are already discriminatory laws at play. The support and pressure from international institutions and foreign states was profound in the struggle towards striking down the AHA. This influence was most visible through condemnatory statements as well as donor funding. It is the foregoing realms of international influence and support that are here discussed with a view to identifying the role they played, the mistakes made and how these actors should in future influence this subject in a manner that effectively guarantees the rights of LGBT people in Uganda.

\section{International influence through donor funding}

For Uganda, whose budget is predominantly dependent on donor funding (up to half of the budget is donor funded), donor countries and international development organisations had wide latitude in influencing and shaping Uganda's human rights regime. This was achieved through initiatives that preconditioned funding to ensuring that the rights of LGBT people are guaranteed. Generally, development has to take into consideration the human rights issues at stake and as such, sources of donor funds can use this as an entry point to impact positively on the rights of LGBT people.

Prior and subsequent to the passing of the Uganda's AHA, leaders of international development organisations and Uganda's donor countries made explicit statements, expressing their discontent with Uganda's AHA. In the USA, Senator Ron Wyden, the chairman of the International Trade Sub-Committee of the US Senate Committee on Finance was of the view that Uganda's AHB constituted a 'gross violation of internationally recognised rights' (Ron Wyden, 2010), making Uganda ineligible for the benefits of the African Growth and Opportunity Act (AGOA). ${ }^{8}$ The UK Prime Minister, David

\section{7}

Notable Ugandan cases in which equality and non-discrimination have been given detailed articulation include Law Advocacy for Women in Uganda v Attomey General Const. Petitions Nos. 13/05/\& 05/06 [2007] UGCC I at 10-I1; Tumukunde v Attomey General \& Another Const. Petition No. 6 of 2005 [2005] UGCC I; Darlington Sakwa \& Another v Electoral Commission \& 44 Others Const. Petition No. 8 of 2006 [2006] UGCC 3 at $\mathrm{I}-\mathbf{2}$.

AGOA was enacted in 2000 in order to encourage economic growth in Africa. Eligible sub-Saharan African countries benefit from trade preferences, including duty-free and quota-free access to the United States, and receive technical assistance and trade capacity support. Uganda has been an eligible beneficiary since AGOA's initial passage. One of the eligibility requirements of AGOA beneficiaries is that they do not engage in gross violations of internationally recognised human rights. 
Cameron similarly made it explicitly clear that '[states] receiving UK aid should adhere to proper human rights' (BBC News, 20II). Similar sentiments were expressed by John Baird (Canada's Minister of foreign affairs), describing the law as 'a serious setback for human rights' (Hui, 2014) while Hillevi Engstrom, (Swedish Minister for International Development Cooperation) made it clear that 'Swedish aid is not unconditional' (Croome, 2014). In March 2014, Sweden froze US $\$$ Iro million intended for the Ugandan government (Croome, 2014). Following the AHB's passage into law, Danish Trade and Development Minister (Mogens Jensen) announced that US\$ro million of aid intended for the Government of Uganda would be redirected to civil society organisations and that future contributions would only be made to non-state organisations in Uganda (Jill, 2014). In June 2014, U.S. National Security Council spokesperson Caitlin Hayden released a statement outlining the U.S. government's response to the AHA (The White House office of the press secretary press release, 2014). The statement amongst others indicated that aid for programs involving the Ugandan Police Force, National Public Health Institute, and the Ministry of Health would be withdrawn or redirected to other sources. The U.S. also cancelled a planned aviation exercise in Uganda. Examples seem inexhaustible. However, while it cannot be concluded with certainty that these responses ultimately led to the striking down of the AHA, it is reasonable to suggest that the pressure exerted by these institutions may have played a role in the decision to ultimately strike down the AHA.

The critical issue to be resolved, however, is whether these institutions (using their financial powers) could have performed better. It is debatable whether decisions to abruptly cut aid are in consonance with the human rights standards that these institutions seek to advance. Note that although donor sanctions are intended to improve the human rights situation in a country of interest, these sanctions are often coercive and if not cautiously applied, may exacerbate discrimination and violence against LGBT people or end up unfairly penalising the general population for the actions of their leaders. Commenting on the decisions taken by international donor institutions and donor countries, Onziema, one of the LGBT activists in Uganda and programme director of Sexual Minorities Uganda (SMUG) condemned this stance, arguing that the decision to defer aid intended for the Uganda Police could be disastrous in light of the fact that there are some cases in which the police has played a role in protecting LGBT people who are at risk of mob justice (John Oliver (YouTube), 20I4). Onziema points out that although the Uganda Police has on occasion harassed LGBT people, it has often come to their rescue (John Oliver (YouTube), 2014). To Onziema, deferring aid suggested that Police would be unable to intervene effectively in instances of violence against LGBT people. A similar dilemma is created when aid intended for the health sector is deferred. The lack of access to health services through restricted aid affects the entire population of Uganda and not just the LGBT community.

The question then is how should donor institutions and countries influence and shape LGBT issues in a manner that holistically takes into account all the rights of the people in a country of interest? Perhaps, as opposed to cutting aid altogether, donor institutions should consider human-rights based funding in which case aid is tied to 
particular policies that further greater tolerance of LGBT people. For instance, funding directed towards the police and judiciary could require the implementation of policies and programs that protect the rights of LGBT people. Similarly, as opposed to cutting funding directed to the health sector (which decision equally affects LGBT people), conditions can be attached to the health fund, requiring the health sector to direct a percentage of the donor funds towards LGBT people since LGBT people continue to be discriminated against in the health sector. Precisely put, the price of international aid should be a commitment to equality, however, donor countries and institutions should move away from negative conditions (characterised by extremes such as abrupt suspension of aid or turning a blind eye to human rights violations) and rather embrace positive conditions.

\section{International influence through condemnatory messages and statements}

The role of international human rights defenders was equally visible in Uganda's struggle to have the AHA struck down. These organisations condemned out-right Uganda's anti-homosexuality laws, thus complementing the local human rights defenders in exerting pressure on the Ugandan government. In the 25th session of the Human Rights Council (HRC) (3-28 March 2014), sexual orientation and gender identity issues formed the crux of the HRC's agenda (Human Rights Council, 2014). Uganda's AHA was brought to the spotlight, with the HRC reiterating the international human Rights obligations of Uganda. A number of international human rights defenders were equally active in this struggle, going ahead to release press statements in condemnation of Uganda's anti-homosexuality laws. Amnesty International, Civil Rights Defenders, Human Rights Watch, University of Pretoria's Center for Human Rights, Office of the High Commissioner for Human Rights, amongst others, through press statements, all condemned Uganda's anti-homosexuality laws, calling upon the government of Uganda to respect and uphold the rights of LGBT people. ${ }^{9}$

Again, the issue that remains to be resolved is whether in respect of previous engagement with LGBT issues, more can be done in the future in the fight to decriminalise all the laws that discriminate against LGBT people. There are reports to suggest that some international human rights defenders have not fared well in creating an environment that furthers the protection of LGBT people in Uganda. For instance, African LGBTI Human Rights Defenders (ALHRD) has previously demonstrated failure of some international

See e.g. Amnesty International "Uganda: Anti-homosexuality bill is inherently discriminatory and threatens broader human rights" 7 January 2010, http://www.civilrightsdefenders.org/news/anti-gay-law-in-ugandaviolates-all-international-conventions/; Centre for Human Rights and Global Justice "Uganda and beyond: Defending global LGBT rights without undermining them" 10 April 2014, http://chrgj.org/event/uganda-andbeyond-defending-global-lgbt-rights-without-undermining-them/; Centre for Human Rights, University of Pretoria "Ugandan government must act to change homophobic culture in light of gay rights activist's killing" I February 2011, http://www.chr.up.ac.za/images/files/news/press/press_release_uganda_homophobic_gay_ activistkilling_Ifeb_20rI.pdf; Office of the High Commissioner for Human Rights "UN human rights office urges Uganda to scrap anti-homosexuality bill ${ }^{n}$, http://www.un.org/apps/news/story.asp?NewsID $=46839$. VZUIUFJRIQs (all accessed 20 January 2016). 
actors to be mindful of the content of their press releases. In their collaboration with international actors, ALHRD notes a number of concerns including press releases containing non-factual information, quoting of activists out of context, failure to consult local activists before embarking on campaigns, disregard of collaborative efforts by ALHRD and exaggeration of violations committed by the government (see e.g. press release by African LGBTI Human Rights Defenders Public statement of warning, 2007). ALHRD notes that such strategies not only put the lives of LGBT people at risk, they have also proven destructive to their work. Oversights such as these should perhaps serve as cautionary tales in future cases of press releases and condemnatory statements. It is particularly critical for international actors to constantly engage with local actors, ensuring that condemnatory statements are a true reflection of the situation on ground. Moreover, in furthering the cause of decriminalisation, international actors should not displace domestic human rights defenders. Rather domestic and international human rights defenders should complement and strengthen each other in the cause of decriminalisation. International human rights defenders should, however, be cautious not to clash with national human rights defenders.

\section{Domestic human rights defenders and non-government organisations (NGOs)}

National human rights defenders and NGOs played a key role in the striking down of the AHA. Some Notable ones include Sexual Minorities Uganda (SMUG), Human Rights Awareness and Promotion Forum (HRAPF), the Civil Society Coalition on Human Rights and Constitutional Law (CSCHRCL), East and Horn of Africa Human Rights Defenders Project (EHAHRDP), Foundation for Human Rights Initiative (FHRI), The Human Rights Centre Uganda (HRCU), Center for Health Human Rights and Development (CEHURD), the Uganda Human Rights Commission (UHRC) and Human Rights Network-Uganda (HURINET). These organisations have, and continue to advocate for tolerance of LGBT people. They have also exerted pressure on the government through press releases, informal dialogue with government officials and stakeholders, symposiums as well as legal aid to LGBT victims of violence. These organisations have played a leading role in challenging anti-homosexuality laws before judicial bodies. Following the accession of the AHB into law, HRAPF challenged the AHA before the East African Court of Justice (EAC)), arguing that the AHA is in violation of the treaty for the establishment of the East African Community which enjoins partner states to govern their populace according to the principles of good governance, democracy, the Rule of Law, social justice and the maintenance of universally accepted standards of human rights (press release by Civil Society Coalition on Human Rights and Constitutional Law (CSCHRCL), 2014). The vehemence of HRAPF was a clear indication of the preparedness of a section of Uganda's populace to challenge laws that discriminate against LGBT people. This case has since been decided by the EACJ (Human Rights Awareness and Promotion Forum (HRAPF) v. Attorney General of Uganda, 2016).

There was speculation that since Uganda's Constitutional Court, in nullifying the AHA, failed to address the substantive human rights issues surrounding the AHA, the 
EACJ would be presented with an opportunity to articulate on these issues. On 16 June 20I6, the EACJ heard final submissions in this case. However, the hearing did not delve into the merits of the case. Rather, its focus was the implication of the nullification of the AHA for the case before the EACJ. In this regard, the Attorney General of Uganda submitted that the case before the EACJ was moot because the AHA had been nullified by Uganda's Constitutional Court (i.e. a competent court of a member state of the East African Community) (HRAPF v. Attomey General of Uganda, 2016: I4). HRAPF, the petitioner, however, contended that despite the said nullification, the fact remained that the action of enacting the AHA was a contravention of provisions of the EAC Treaty and that while it was in force, the rights of the LGBTI community of Uganda were undermined (HRAPF v. Attorney General of Uganda, 20I6: 9). Had the EAC) preferred the argument of HRAPF, there was a possibility that the substantive aspects of the AHA would have been addressed.

However, on 27 September 2016, the EACJ, consisting of a panel of three judges led by Ugandan Justice, Monica Mugenyi, held that the EACJ could not pronounce on the matter since the AHA 20I4 had been annulled by the Constitutional Court in Uganda. The EACJ categorically ruled as follows:

In the result, faced with a reference that is devoid of the sufficient proof of the public importance of its subject matter and recognition of the legislative function of the legislature vis $a$ vis the role of courts, we are unable to exercise our judicial to adjudicate on a matter that is moot and hypothetical. We so hold... (HRAPF v. Attorney General of Uganda, 2016: 66).

Once again, the case pertaining to the AHA was dismissed based on technicalities, with the EACJ, just like the Constitutional Court, failing to take this as an opportunity to pronounce itself on the merits of the case. However, as HRAPF, the petitioner, has aptly submitted:

[Despite the defeat] HRAPF is proud of its role in this case, as this is the first time that an international human rights tribunal in Africa has heard a case concerning violations against LGBTI [...] The case has also brought together Ugandan, East African and African activists to take their destiny in their hands and challenge laws that threaten the rights of LGBTI persons even at the intentional level (Nathan 2016).

The determination and zeal that echoes through the above statement cannot be overemphasized. If anything, it underlines the role that domestic human rights defenders have played in advancing the rights of LGBTI people in Uganda and the East African region generally. 
Through press releases, these organisations have also created a platform through which the international community can engage with local human rights defenders (by clearly suggesting ideal steps and actions to be taken by international actors). ${ }^{10}$ Moreover, constitutional review can only be relevant if there are organised claimants who actively lodge complaints to adjudicators or courts. The critical role of Ugandan NGO's and human rights defenders in setting the constitutional review process into action was evident in the petition in the Oloka-Onyango case.

These organisations have remained resolute and courageous advocates despite the risks they face as defenders of LGBT rights. They constantly engage in informal debates with Uganda's parliamentarians without necessarily having to quote any international human rights instrument. Perhaps to further inspire the continued fight against all discriminatory laws, Uganda's human rights defenders and NGOs can draw inspiration from South Africa's approach. In 1996, the South African government approved a new constitution. This was the first constitution to include sexual orientation as a prohibited ground of discrimination. The progressiveness of the South African Constitution was, however, in serious disconnect with South Africa's predominantly conservative society at the time. Speaking with one voice, the gap between a progressive legal code and a conservative society became the arena for action by human rights defenders and gay rights groups between 1994 and 1998 . In particular, gay rights groups used the constitution's broad provisions as an opportunity to educate South Africans about democracy (Massoud, 2003: 301-307). In 1998, two years after ratification, the National Coalition for Gay and Lesbian Equality (since renamed the 'Gay and Lesbian Equality Project') successfully litigated against the old regime's anti-gay sodomy laws. Even without drawing on international standards, Uganda's Constitution has a relatively broad catalogue of constitutional guarantees which are sufficient to protect LGBT people. However, there is still a disconnect between these guarantees and Uganda's conservative society (with many Ugandans totally ignorant of the content of the Constitution). For Uganda's national human rights defenders and NGOs, dealing with this gap will be a considerable challenge, as part of preparing the ground for decriminalisation.

\section{Faith-based organisations}

Religion can and does provide a framework for human rights to be protected. However, religious pressure (both nationally and internationally) has contributed to Uganda's homophobia. Interestingly, however, there is a section of Ugandan religious leaders who

Io See e.g. Civil Society Coalition on Human Rights and Constitutional Law (CSCHRCL) "From Uganda: Guidelines for action against the Ant-Homosexuality Bill" 5 March 2014, http://paper-bird.net/2014/03/05/ from-uganda-guidelines-for-action-against-the-anti-homosexuality-bill/ ; Civil Society Coalition on $\mathrm{Hu}-$ man Rights and Constitutional Law (CSCHRCL) "Guidelines to national, regional, and international partners on how to offer support now that the anti-homosexuality law has been assented to" 4 March 2014, http://www.blacklooks.org/2014/03/guidelines-to-ugandan-national-regional-international-partners-onsupport-around-the-anti-homosexuality-bill/; International Gay and Lesbian Commission "SMUG: Outrage at the Passing of the Anti-Homosexuality Bill 2009" 20 December 2013, http://iglhrc.org/content/smug-outragepassing-anti-homosexuality-bill-2009 (all accessed 20 January 2016). 
are totally against laws that discriminate against LGBT people. The divergence in religious opinion suggests that religious arguments can in fact be relied on to further the case for decriminalisation, thus creating an environment where Uganda ultimately adheres to the international human rights standards on this subject. Central to the arguments of some religious leaders is the idea that homosexuality is sinful, with some religious adherents convinced that it is a disgraceful act that can be cured. ${ }^{\text {II }}$ Pastor Stephen Langa and Pastor Martin Ssempa (also Chairperson of the National Taskforce Against Homosexuality in Uganda) are some of the religious leaders who were very vocal in pushing for the AHA. ${ }^{22}$ They often echoed the views of American evangelists like Rick Warren and Scott Lively. Advocacy for criminalisation by these religious leaders has sparked panic across a section of Uganda's population, ultimately contributing to homophobia. A notable case is the viral YouTube video titled 'Eat Da Poo Poo' by Pastor Ssempa, showing explicit gay pornography. The video graphically described male same sex acts in church, having the effect of depicting LGBT people as a disgrace to Uganda's society (YouTube "EAT DA POO POO", 2010). Note, however, that Uganda's laws against homosexuality are secular, hence suggesting that religion has no place in determining the legal relevance of antihomosexuality laws. However, religious arguments remain a powerful justification for these laws in Uganda. These religious justifications have been hard to challenge and as Sadgrove et al. put it, these justifications have had the effect of 'manipulating social anxieties' (Sadgrove 2012 et al. 106). But with some religious leaders now openly taking a view that furthers tolerance, religious influence (through faith-based organisation) is another layer of reform that will likely create a conducive environment for international human rights standards to be practically and effectively applied.

There is a section of Ugandan religious leaders that takes the view that anti-homosexuality laws are not only offensive but also an attack on the very foundations of religion. Incidentally, some of the American evangelists (such as Rick Warren and Scott Lively) who have been consistently quoted by Ugandan religious leaders (such as Pastor Ssempa and Pastor Langa) appear to be taking a more tolerant approach to LGBT issues, thus making some of the arguments of the Ugandan leaders fundamentally flawed. Rick Warren, for instance, has noted as follows:

We can never deny or water down what God's word clearly teaches about sexuality. At the same

These are the popular arguments of religious leaders who are in favour of criminalisation of homosexual conduct. Pastor Ssempa Martin and Pastor Langa Stephen championed the anti-homosexuality Bill, albeit indirectly. For instance, Pastor Ssempa is on record for showing gay pornography in church settings and publicly vouching for the anti-homosexuality law through the media. On the foregoing two aspects, see "Martin Ssempa discusses homosexuality ${ }^{n}$ https:/www.youtube.com/watch? $v=17$ CgTgAms (accessed ro February 2016) in which Ssempa states as follows: "we are making legislation to make sure that sodomy and homosexuality never sees the light of day in this land of the pearl of Africa."; "Morning @NTV: Pastors Martin Ssempa and Solomon Male on the Anti-Gay Law" https://www.youtube.com/watch?v=LA8nxRwdKM (accessed ro February 2016) in which Ssempa lauds the Anti-Homosexuality Act as a victory well won in protecting the African family from western powers. Pastor Langa is equally on record for delivering seminars, in which he essentially echoes Lively's 'research' on the history of the "gay movement". Langa adds that there is a force that is behind the gay movement and this movement has to be attacked with force since the movement is on a mission to sodomise children. On the foregoing issue see https://www.youtube.com/watch?v=KhRXBN8llPU (accessed 20 February 2016). 
time, the Church must stand to protect the dignity of all individuals, just as Jesus did and commanded all of us to do... Since God created all, and Jesus suffered and died for all, then we are to treat all with respect (Kumar, 2014).

Other Ugandan religious leaders have also taken a firm position against anti-homosexuality laws. Canon Gideon Byamugisha, an Anglican religious leader and Christian Aid goodwill ambassador on HIV/Aids has voiced the concern that anti-homosexuality laws hinder the fight against HIV/AIDS among LGBT people, equating these laws to 'state-legislated genocide against a specific community of Ugandans' (The Guardian, 2009). Reverend Fred Komunda, another Anglican religious leader has also consistently reminded his fellow religious leaders that '[they] aren't just giving sermons. They are a real support network' and this ought to be reflected in the manner in which all believers are treated (Carrington, 2014). Bishop Christopher Ssenyonjo, a retired Anglican religious leader, has openly embraced LGBT people in his religious gatherings regardless of their sexual orientation (Muhumuza, 2014). Bishop Ssenyonjo has also out-rightly opposed the idea of criminalisation of homosexual conduct and in some cases expressly dismissed the derogatory and offensive arguments (about LGBT people) which are often advanced by intolerant religious leaders (Muhumuza, 2014). He continues to stand in solidarity with various LGBT organisations, earning himself the status of 'an elder' in Uganda's LGBT community (Muhumuza, 2014). Father Musaala, a catholic priest, has also openly embraced LGBT people, going ahead to offer pastoral ministry to those who are displaced on grounds of sexual orientation (Stewart, 2014). Father Musaala takes the view that anti-homosexuality laws contradict the teachings of the catholic faith particularly in terms of how LGBT people should be treated. The divergence of religious opinion within the same religion was well-portrayed in Zalcman's interview of two Muslim religious leaders. Zalcman reports as follows:

I met one imam who had been educated in Egypt and worked in Saudi and essentially told me he wished sharia law could be enacted in Uganda. Then, I met another imam who said, 'today you say you hate gay people, tomorrow God will give you a gay son. What will you do then?' (Carrington 2014).

The above interview and arguments of religious leaders not only reveal the divergence of opinion among religious leaders but also the possibility of religious tolerance. In an environment where religion has previously been relied on to vouch for anti-homosexuality laws, the emergence of a breed of religious leaders who advance the message of tolerance is to be welcomed and fully exploited. To achieve the goal of total decriminalisation in accordance with established international human rights standards as consistently underscored in this article, a platform should be created for debate and dialogue where religious leaders can re-assess the authenticity of their religious interpretations. Further, with the growing body of literature on alternative religious interpretations that further tolerance, effort needs to equally focus on supporting the development of 
grounded research which builds upon international human rights standards on tolerance and diversity. Moreover, other actors (such as the judiciary, human rights defenders and the international community) should engage with faith-based organisations with a mind-set that views religion as a double edged sword which can be wielded creatively and resourcefully to enhance the rights of LGBT people in accordance with the established international human rights standards. A religious entry point is extremely critical and should not be taken lightly in light of the fact that the majority of Uganda's population is staunchly religious.

\section{Conclusion}

International human rights norms provide a higher standard for the protection of LGBT people. However, these norms cannot function on their own. In terms of furthering the cause of decriminalisation of anti-homosexuality laws in Uganda, they will continue to make little or no meaningful difference. It is important for the judiciary, international and domestic human rights defenders and faith-based organisations to draw inspiration from the deep sentiments of Uganda's populace so that in developing approaches to combat discriminatory laws, local context is as far as is possible taken as a source of advocacy, rather than relying exclusively on international law. To ignore Uganda's local context would lead to charges of colonialism, consequently undermining well-intentioned human rights norms.

\section{References}

Journal articles and books

Hopkins, K. (2002). The effect of an African Court on the domestic legal orders of African states. African Human Rights Law Journal, 2: 234-25I

Massoud, M. (2003). The Evolution of Gay Rights in South Africa. Peace Review, 15: 301-307.

Petrova, D. (2013). The use of equality and anti-discrimination law in advancing LGBT rights. In: Corinne, Lennox \& Matthew, Waites (eds.), Human rights, sexual orientation and gender identity in the commonwealth: struggles for decriminalisation and change. 477-505. London: School of Advanced Study, University of London.

Sadgrove, J., Vanderbeck, R.M., Andersson, J. Gill V. and Ward, K. (2012). Morality plays and money matters: Towards a situated understanding of the politics of homosexuality in Uganda. The Journal of Modern African Studies, 50: 103-129.

Strand, C. (2013). The rise and fall of a contentious social policy option - narratives around the Ugandan AntiHomosexuality Bill in the domestic press. Journal of African Media Studies, 5: 275-294.

Stychin, F.C. (2004). Same-sex sexualities and the globalisation of human rights discourse. McGill Law Journal, 49: 95I-968.

Tamle, S. (2009). A Human Rights Impact Assessment of the Ugandan Anti-homosexuality Bill 2009, The Equal Rights Review, 4: 49-57.

Viljoen, F. (2007). International human rights law in Africa. Oxford: Oxford University Press.

Viljoen, F \& Louw, L. (2007). State compliance with the recommendations of the African Commission on Human and Peoples' Rights 1994-2004. The American Journal of International Law ror: 1-34.

Xie, N. (2010). Legislating hatred: Anti-gay sentiment in Uganda. Harvard International Review, 32: 6. 


\section{Laws and Cases}

Anti-Homosexuality Act of Uganda, 2014.

Constitution of the Republic of Uganda of 1995 .

Human Rights Awareness and Promotion Forum (HRAPF) v. Attorney General of Uganda, Reference No. 6 of 2014

Kasha Jacqueline, David Kato and Onziema Patience v Rolling Stone Publications Limited and Giles Muhame Miscellaneous Cause No. 163 of 2010.

Magaji v The Nigerian Army (2008) 2-3 SC 32.

Mukasa and Another v Attorney-General (2008) AHRLR 248 (UgHC 2008).

National Coalition for Gay and Lesbian Equality v Minister of Justice 1998 (I2) BCLR I (CC).

National Coalition for Gay and Lesbian Equality and Others v Minister of Home Affairs and Others 2000

(2) SA I (CC); Fourie v Minister of Home Affairs 2005 (3) SA.

Penal Code Act Chapter 120 of 1950 as amended in 2007.

Professor J. Oloka-Onyango \& Others v Attorney General of Uganda Constitutional Petition 8 of 2014.

Toonen v Australia, Communication No. 488/1992, U.N. Doc CCPR/C/5o/D/488/1992 (1994).

\section{Websites}

Amnesty International (2010). 'Uganda: Anti-homosexuality bill is inherently discriminatory and threatens broader human rights' 7 January 2010. http://www.civilrightsdefenders.org/news/anti-gaylaw-in-uganda-violates-all-international-conventions/ (accessed is January 2016).

Anugrah Kumar (2014). 'Rick Warren squashes rumours; says he strongly opposes Uganda's AntiHomosexuality Law' 3 March 2014

http://m.christianpost.com/news/rick-warren-squashes-rumors-says-he-strongly-opposes-ugan-

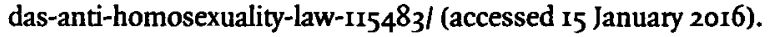

BBC News (2011). 'Cameron threat to dock some UK aid to anti-gay nations' 30 October 2011. http://www.bbc.com/news/uk-15511081 (accessed 15 January 2016).

Centre for Human Rights, University of Pretoria (20II). 'Ugandan government must act to change homophobic culture in light of gay rights activist's killing' I February 2011.

http://www.chr.up.ac.za/images/files/news/press/press_release_uganda_homophobic_gay_ activistkilling_Ifeb_20II.pdf (accessed 15 January 2016).

Centre for Human Rights and Global Justice (2014). 'Uganda and beyond: Defending global LGBT rights without undermining them' Io April 2014.

http://chrgj.org/event/uganda-and-beyond-defending-global-lgbt-rights-without-undermining-them/ (accessed is January 2016).

Civil Society Coalition on Human Rights and Constitutional Law (2014). 'From Uganda: Guidelines for action against the Anti-Homosexuality Bill', 5 March 2014.

htup://paper-bird.net/2014/03/05/from-uganda-guidelines-for-action-against-the-anti-homosexuality-bill/ (accessed is January 2016).

Civil Society Coalition on Human Rights and Constitutional Law (2014). 'Guidelines to national, regional, and international partners on how to offer support now that the anti-homosexuality law has been assented to', 4 March 2014. http://www.blacklooks.org/2014/03/guidelines-to-ugandannational-regional-international-partners-on-support-around-the-anti-homosexuality-bill/ (accessed ro March 2016).

Civil Society Coalition on Human Rights and Constitutional Law and Human Rights Awareness and Promotion Forum (2013). 'Protecting 'morals' by dehumanising suspected LGBTI persons? A critique of the enforcement of the laws criminalising same-sex conduct in Uganda.' www.hrapf.org/sites/.../section_145_research_report_full_version.pdf (accessed ro December 2015). 
Colin Stewart (2014) 'Ugandan priest: 10 reasons to repeal anti-gay law' 5 May 2014. http://76crimes.com/2014/05/05/ugandan-priest-1o-reasons-to-repeal-anti-gay-law/ (accessed ro March 2016).

International Gay and Lesbian Commission (2013). 'SMUG: Outrage at the Passing of the Anti-Homosexuality Bill 2009" 20 December 2013. http://iglhrc.org/content/smug-outrage-passing-anti-homosexuality-bill-2009 (accessed to March 2016).

Daisy Carrington (2014) 'On homosexuality: Uganda's religious leaders' 16 October 2014. http://edition.cnn.com/2014/10/16/world/africa/on-homosexuality-ugandas-religious-leaders/ (accessed ro March 2016).

Jameson, Parker (2014). 'American pastor who helped Uganda create 'Kill the gays' law will be tried for crimes against humanity.' http://www.addictinginfo.org/2014/12/08/american-pastor-who-helped-ugandacreate-kill-the-gays-law-will-be-tried-for-crimes-against-humanity/ (accessed 10 March 2016).

Mahoney Jill (2014). 'Uganda's Anti-Gay laws causes significant cuts to foreign aid' 26 February 2014. http://www.theglobeandmail.com/news/world/ugandas-antigay-law-causes-significant-cuts-toforeign-aid/articler7112073/ (accessed ro March 2016).

Nathan, Melanie (2016). 'International human rights court in Africa delivers Judgment: Blow in historic first LGBT case' 27 September 2016. https://oblogdeeoblogda.me/2016/09/27/international-human-rightscourt-in-africa-delivers-judgment-blow-in-historic-first-lgbt-casel (accessed 7 February 2017).

Morrison, Rwakakamba (2014). 'Uganda's 'Kill the Gays' bill: Pastor Martin Ssempa and the anti-gay lobby.' https:/www.opendemocracy.net/transformation/morrison-rwakakamba/ugandas-kill-gays-billpastor-martin-ssempa-and-antigay-lobby (accessed is January 2016).

'Martin Ssempa discusses homosexuality' https://www.youtube.com/watch?v=17C9TgAms (accessed to March 2016).

'Morning @NTV: 'Pastors Martin Ssempa and Solomon Male on the Anti-Gay Law.' https://www.youtube.com/watch?v=LA8nxRwdKM (accessed ro March 2016).

New York Times (2011). 'Ugandan who spoke up for gays is beaten to death' 27 January 2011. http://www.nytimes.com/2011/or/3o/weekinreview/3ogettleman.html?_r=o (accessed Io March 2016).

Office of the High Commissioner for Human Rights 'UN human rights office urges Uganda to scrap anti-homosexuality bill.' http://www.un.org/apps/news/story.asp?NewsID=46839\#.VZUlUFJRIQs (accessed Io March 2016).

Philippa Croome (2014) 'Sweden suspends some aid to Uganda over anti-gay law' 6 March 2014. http://uk.reuters.com/article/2014/03/06/uk-uganda-aid-sweden-idUKBREA2509420140306 (accessed ro March 2016).

Press release by African LGBTI Human Rights Defenders (2007). 'African LGBTI Human Rights Defenders Public statement of warning' 31 January 2007.http://www.blacklooks.org/2007/02/african_lgbti_ human_rights_defenders_-_public_statement_of_warning/ (accessed ro March 2016).

Press release by Civil Society Coalition on Human Rights and Constitutional Law (CSCHRCL) 'Uganda's Anti-Homosexuality Act challenged before the East African Court of Justice' 30 April 2014. http://www. hrapf.org/sites/default/files/publications/I4_04_23_cschrcl_press_release_upon_eacj_reference_ filing_final.pdf (accessed ro March 2016).

Remarks of Human Rights Council to Uganda at the 25th Session of the Human Rights Council 2014 in Geneva (3-28 March 2014). http://www.faruganda.org/index.php/news-and-events/82-humanrights-council-remarks-march-session-2014.html (accessed ro March 2016).

Rodney Muhumuza (2014). 'Christian cleric openly ministers to Ugandan gays, urges toletance' 29 March 2014. http://globalnews.ca/news/1238715/christian-cleric-openly-ministers-to-ugandan-gays-urgestolerancel (accessed 1o March 2016).

Ron Wyden (2010). 'Ugandan Anti-Homosexuality proposal violates human rights standards' 3 March 20ro. http:/I www.wyden.senate.gov/news/press-releases/state-dept-to-wyden-uganda-anti-homosexualityproposal-violates-human-rights-standards (accessed Io March 2016). 
Stephen Hui (2014). 'Foreign Affairs MinisterJohn Baird denounces Uganda's anti-gay Legislation' 24 February 2014. http://www.straight.com/news/593311/foreign-affairs-minister-john-baird-denounces-ugandasanti-gay-legislation (accessed ro March 2016).

The Guardian (2009). 'Ugandan church leader brands anti-gay bill genocide' 4 December 2009. http://www.theguardian.com (accessed ro March 2016).

The White House Office of the Press Secretary Press Release 'Statement by NSC Spokesperson Caitlin Hayden on the Response to Uganda's Enactment of the Anti-Homosexuality Act' I9 June 2014. https://www.whitehouse.gov/the-press-office/2014/06/19/statement-nsc-spokesperson-caitlin-hayden-responseuganda-s-enactment-an (accessed ro March 2016).

YouTube 'Last Week Tonight with John Oliver: Pepe Julian Onziema Interview Pt. II' 29 June 2014. https://www.youtube.com/watch?v=QJkiWwMKwSo (accessed ro March 2016).

YouTube "EAT DA POO POO" 24 May 2010. https://www.youtube.com/watch?v=euXQbZDwVow (accessed ro March 2016).

\section{International instruments}

The African Commission made a number of interesting pronouncements: meeting at its 55th Ordinary Session held in Luanda, Angola, from 28 April to 12 May 2014.

Resolution 275, on the Protection against Violence and other Human Rights Violations against Persons on the basis of their real or perceived Sexual Orientation or Gender Identity (accessed 26 May 2017).

UN Committee on Economic, Social and Cultural Rights (CESCR), General comment No. 20: Non-discrimination in economic, social and cultural rights (art. 2, para. 2, of the International Covenant on Economic, Social and Cultural Rights), 2 July $2009, \mathrm{E} / \mathrm{C} .12 / \mathrm{GC} / 20$.

http://www.refworld.org/docid/4a6096If2.html (accessed I4 February March 2016).

UN Committee on the Rights of the Child (CRC), General comment No. 4 (2003): Adolescent Health and Development in the Context of the Convention on the Rights of the Child, I July 2003, CRC/ GC/2003/4. http://www.refworld.org/docid/4538834fo.html (accessed 14 February 2016).

UN Committee Against Torture (CAT), General Comment No. 2: Implementation of Article 2 by States Parties, 24 January 2008, CAT/C/GC/2. http://www.refworld.org/docid/47ac78ce2.html (accessed 14 February 2016).

Yogyakarta Principles of 2006. http://www.yogyakartaprinciples.org/ (accessed I4 February 2016). 